Bernt Mфller

\title{
Udviklingstendenser i orddannelsen i teknisk fransk i informatikterminologisk belysning
}

\begin{abstract}
This article outlines current trends in the word formation of French technical LSP.

First, a brief review of a fairly traditional, exemplified word formation taxonomy is given also showing the multiplicity of informatique word formation models. The article goes on to survey recent studies in the terminology of information technology. Observations in these studies and in studies in general technical terminologies suggest an increasing trend in the word formation of technical LSP towards a large variety of (combinations of) traditional models, often coupled with brachygraphical techniques; the LSP of informatique further contains a high frequency of semantic neologisms. Finally, perspectivating questions are raised.
\end{abstract}

\section{Indledning}

Med denne artikel har jeg til hensigt - efter at have blændet lidt op for den lingvistiske og samfundsmæssige kontekst - at give en oversigt over orddannelsen i fransk belyst ved gængs taksonomi og med eksemplaris$\mathrm{ke}$, fortrinsvis informationsteknologiske neologismer. Med dette som basis vil jeg dernæst rette fokus mod informatikken og dens skriftlige terminologi, som den beskrives og analyseres af sprogforskere for at finde svar på spørgsmålet: hvilke måder at danne ord på er særligt produktive eller på anden måde bemærkelsesværdige inden for informatikterminologien ? Hovedsagligt på grundlag heraf vil jeg forsøge mig med et foreløbigt, summarisk udtryk for sandsynlige tendenser for udviklingen i orddannelsen i teknisk fransk samt rejse nogle centrale spørgsmål, hvis afklaring for fleres vedkommende ville kunne øge vores indsigt i nogle af de mekanismer, der spiller - og måske i stigende grad vil spille - ind i orddannelsen.

I min behandling vil jeg benytte gængs terminologi, herunder leksikalsk enhed som fællesbenævnelse for ord og syntagmer, der består af henholdsvis ét, henholdsvis to el. flere graford (som i hv. ordinateur og additionneur-soustracteur, hv. machine à calculer (3 graford) og ingénieur électricien (2 graford)). Adjektivet simpelt vil blive brugt om ord med ét morfem el. én morfematisk enhed (hvor morfem er den gængse benævnelse for mindste betydningsbærende enhed i et ord) - eks: souris - 
mens adjektivet kompleks anvendes om leksikalske enheder med to eller flere morfemer, eks. ordin/ateur (ordin- og -ateur), code objet (code og objet). Benævnelsen term forekommer, hvor der er tale om en sådan enhed i terminologilærens forstand, og/eller hvor enheden er normaliseret. Dog vil jeg bruge terminologi for alle leksikalske enheder inden for informatikken.

Hvor det ikke burde kunne misforstås, anvender jeg løbende benævnelsen "ord" om både ord i snæver forstand og om syntagmer.

Benævnelsen neologisme skal, hvor konteksten ikke er mere præcis, opfattes som synonym til leksikalsk enhed (inden for informatikken). Det bemærkes, at informatikterminologien i artiklen opfattes under ét som et synkront, "nyt" teknisk fagsprog.

Endelig skal adjektivet "engelsk" forstås som "anglo-amerikansk".

Orddannelsen forekommer at være en lingvistisk disciplin med ét ben i grammatikken, ét i leksikologien. Den bygger på morfologien, som beskæftiger sig med et ords interne grammatiske struktur i modsætning til syntaksen, som jo angiver regler for et ords kombinationsmuligheder med andre ord i en sætning. Orddannelsen interesserer sig dog ikke lige meget for alle morfologiens basiskomponenter; bøjningsmorfemerne (fleksiver; eks: pluralis-s i ordinateur $\underline{\text { s) }}$ er ganske vist uomgængelige ved en morfematisk segmentering af ord i en tekst, men bidrager ikke til mængden af disponible begrebsdifferentierende morfemer, da de er er rent grammatiske byggestene.

I de seneste årtier, hvor interessen for analyse på ordplanet især i den engelsksprogede verden synes at være mindre end analyse i f.eks. teoretisk sætningssyntaks, er det ikke uinteressant at bemærke en stigende optagethed i den fransksprogede verden af neologien, læren om de nye ord, en optagethed der, som vi kort skal se, afspejles i på en gang intra- og ekstralingvistiske forhold.

En årsag til, at disciplinen orddannelse i de seneste årtier ikke har fået den store opmærksomhed, er sikkert den hidtil ret udbredte antagelse om strukturernes relative stabilitet og den deraf følgende relativt begrænsede interesse for diakrone studier. På et leksikalsk-strukturelt plan ændrer sproget sig imidlertid til stadighed, omend kun gradvist, og det afspejles måske mest tydeligt indenfor de tekniske registre, hvor tilgangen af nye ord til benævnelse af nye genstande, processer og begreberer er enorm og kommunikationskonteksterne meget varierede. Jo mere gennemgribende teknologiske landvindinger, desto større grad af afsmitning horisontalt 
som vertikalt i og mellem fagsprogene, og desto større sandsynlighed for, at kvalitativt som kvantitativt ændrede orddannelsemønstre overføres til almensproget, først i form af enkelte ord, siden i form af bagvedliggende orddannelsesmæssige strukturer (som f.eks. en foretrukken måde at danne ord på, en hyppigere anvendelse af et (evt. nyt) suffiks, osv.).

Ud over de indledningsvist nævnte formål har jeg endnu ét, nemlig at vise mangfoldigheden i måder at danne ord på i moderne teknisk fransk. At mangfoldighed ikke er noget, der giver sig selv, skal forstås på baggrund af to korrelerede forhold.

For det første noget, der ligner en tradition for i Frankrig at mene, at det franske sprog, omend rigt på uforlignelige kvaliteter, er underlagt nogle strukturelle bindinger, der gør, at det på ordplanet ikke har samme fleksibilitet som en række andre, "konkurrerende" sprog, især når det gælder om at bruge allerede eksisterende franske ord som basis for nye, semantisk og/eller syntaktisk beslægtede. Op igennem vort århundrede er det igen og igen blevet understreget (f.eks. af L. Guilbert, H. Mitterand), at de germanske sprogsystemer i modsætning til det franske har fordelen af at kunne danne nye ord ved den blotte sammensætning af andre (eksisterende) ord, mens fransk må ty til analytiske omskrivninger, og der høres røster om, at fransk generelt har utilstrækkelige aflednings- og sammensætningsressourcer (f.eks. S. Ullmann; J. Marouzeau), at fransk ikke i samme grad som f.eks. italiensk formår at udnytte afledningens muligheder til f.eks. at skabe diminutiver eller lave afledningsord ud fra sammensætnings- og initialord (A. Dauzat), at fransk kun i ringe grad udviser fantasi, når det drejer sig om at danne afkortelsesord (G. Haensch \& A. Lallemand-Rietkötter; Boissy 1988). Alle anklagepunkter, der ikke er specielt møntet på den konservative sprogbruger, men lige så meget på et stift sprogsystem.

For det andet noget, der også ligner en tradition, nemlig fransk officiel purisme og sproglovgivning, der bl.a. skal ses som en reaktion på en (påstået) sprogbrugskrise. Denne giver sig udslag i brugen af "franglais", hvis elementer sjældent er kompatible med det franske fonologiske og ortografiske system (det samme gælder selvfølgelig ordbøjning og ordføjning), i stedet for mindst lige så gode franske ord - hvis de altså findes. I 70-erne indså myndighederne, at anglomanien - som ganske vist er udpræget mangfoldig i sine realisationer, men altså som oftest "ufransk" - kun kan bekæmpes via lovgivningen. Fra 1973 er der jævnligt blevet nedsat officielle terminologikommissioner, hvis primære opgave inden 
for et fagområde som f.eks. informatik det er at udarbejde ministerielle bekendtgørelser med obligatoriske (evt. anbefalede) franske termækvivalenter til de engelske neologismer, som (ellers) direkte eller i lettere modificeret form overtages og bruges af franske fagfolk i franske diskurser. I forbindelse med en banebrydende sproglov fra 1975, opstod nødvendigheden af en juridisk definition af, om et givet ord er fransk eller ej. Her refererer man i dag til ca. 3000 kodificerede franske termer og deres forbudte (evt. frarådede) fremmede pendanter - i praksis angloamerikanske. Terminologikommissionernes virksomhed er således udtryk for et $\emptyset$ nske om via normeringsindgreb at sætte skub i realiseringen af "franske" orddannelsespotentialer og den dertil knyttede brug.

\section{Orddannelseskategorier}

Orddannelsen, som den fremstår i de mange franske traditionelle grammatikker og andet materiale såsom neologismeoversigter, fagsprogsværker og den specifikke orddannelseslitteratur udviser m.h.t. opdeling i kategorier mere eller mindre principielle divergenser alt efter "ideologisk udgangspunkt", om synsvinklen primært er statisk-analytisk eller nydannelsesproces-orienteret, om vægten lægges på (typisk) funktion, grafi eller etymologi. Det vil føre for vidt her at behandle divergenserne; som ledetråd gælder, at jo mere fagsprogsorienteret litteratur, desto større behov for og tendens til nuanceret taksonomi. Mit formål med dette afsnit er ikke kun at præsentere klassisk orddannelsestaksonomi flankeret af eksempler, men også - omend sekundært - at vise eksempler på mangfoldigheden i informatikterminologiens orddannelsesmønstre. Derfor har jeg valgt at lade mig inspirere af nyere, fagsprogsorienterede kilder - uden derved at distancere mig fra en mere almensproglig, tilnærmet konsensus-taksonomi - især det eneste eksisterende Gesamtwerk for fransk teknisk sprogs vedkommende, R. Kokourek: "La langue française de la science et de la technique " (Wiesbaden 1982). De kategorier, der synes at være specielt vigtige for teknisk terminologi er følgelig mere detaljeret behandlet. Eksemplerne er primært hentet fra informatikken, sekundært (om praktisk muligt) fra andre tekniske registre.

\subsection{Afledning (derivation)}

Traditionelt helt centralt står afledning el. derivation, der i de fleste grammatikker udover suffiksering også omfatter præfiksering. Ved afledning tilføjes et affiks til en eksisterende rod, evt. faste kombinationer af rødder, eks: multiplex (A) -> multiplexer (V), som vi kalder en suffiksering; multiplexer $(\mathrm{V})$-> démultiplexer $(\mathrm{V})$ er et eksempel på præfikse- 
ring (vedr. multiplex, se i øvrigt 2.9 in fine). Præ- og suffikser har mange fælles karakteristika: De er begge per definition et bundet morfem (dvs. kan ikke optræde frit i en sætning), hvorimod den rod, de lægger sig til per definition er et frit morfem (traditionelt i form af et substantiv, adjektiv, verbum, evt. adverbium). De optræder desuden altid i hv. præ- og postposition i forhold til roden, aldrig begge dele; derimod kan man godt have et ord, der både bærer et præfiks og et suffiks - man taler da om parasyntetisk afledning, eks: multiplex (A) -> démultiplexer (V). Nogle affikser har fået prædikatet "franske" - også kaldet "populaires" -, andre "græske" eller "latinske", kaldet "savants", lærde. De franske - der er overtaget fra især latin på et meget tidligt tidspunkt - har som regel undergået en grafisk ændring, f.eks: lat. inter - -> fra entre -. Ofte er både et fransk og et konkurrerende lærd dublet-affiks produktive i nye afledninger, eks: entraxe (N); intermémoire (N/A). Præ- og suffikser har også uligheder: f.eks. ændrer suffikserne typisk udgangsordets klasse, hvilket aldrig er tilfældet med præfikser, der til gengæld ofte har et mere præcist semantisk indhold.

(Eksempler på "hybridafledninger": se 2.9 in fine).

\subsection{Sammensatning (komposition)}

Den anden helt centrale måde at danne ord på er ved sammensætning el. komposition, hvor to el. flere frie morfemer $(\mathrm{N}+\mathrm{N}$ : programme-produit; $\mathrm{V}+\mathrm{N}$ : compte-carte; $\mathrm{N}+\mathrm{P}+\mathrm{N}$ : carte-à-bande; m.fl.) forenes til en grafisk kontinuert enhed - en sammensætning eller et kompositum - dvs. ét graford (dog praktisk taget næsten altid med bindestreg). Nogle kilder vil have denne kategori til også at omfatte grafisk ikke kontinuerte leksikalske enheder, som f.eks. af typen $\mathrm{N}+\mathrm{N}$ : programme utilisateur og $\mathrm{N}+\mathrm{P}+\mathrm{N}$ : programme de commande, hvilket som opposition til afledning er logisk nok, men resulterer i en grov inddeling (se 2.8). Vedrørende ord af typen télécommunication og microscope, hvor mindst ét, hv. alle elementer er græske og/el. latinske, og som nogle forfattere medtager i denne kategori: se 2.9, der in fine viser et hybrideksempel, hvor sammensætning indgår.

\section{3 "Ex nihilo"}

Ved "ex nihilo"-orddannelse konstrueres et ord ved i princippet umotiveret benævnelse $\mathrm{i}$ form af et simpelt ord, eksempel (dog ikke helt korrekt p.g.a. inspiration fra græsk "chaos"): gaz. Traditionelt er denne måde at danne ord på af meget ringe betydning, også indenfor videnskaberne. 
En overgang diskuterede man - og opgav hurtigt - *nabla og *blabla som afledningsegnede ækvivalentforslag til software og hardware.

\subsection{Reduplikation og onomatopoietisk orddannelse}

To ligeledes traditionelt perifere måder at danne nye ord på i teknisk fransk er fordobling af stavelse(r) og lydefterligning, eks: ronron $(\mathrm{N}), \mathrm{hv}$. flip-flop $(\mathrm{N})$, bip $(\mathrm{N})$.

\subsection{Leksikalsk brachygrafi}

Diverse former for sammentrækning eller leksikalsk brachygrafi udgør en meget heterogen, i traditionel litteratur forsømt gruppe af overordentlig stor praktisk betydning for videnskabelig og især teknisk terminologi. Leksikalske enheder, bestående af 1) ét, eller 2) flere graford, vil ofte fremtræde i for- eller afkortet udgave.

For den første gruppes vedkommende taler vi om afkortelse (troncation), hvis antallet af stavelser i enheden reduceres. Undergrupperne er afærese (bortskæring af initial del af enheden, eks: autobus -> bus - meget sjælden form i 1-grafords enheder); synkope (bortskæring af medial del, cf. téléinformatique -> télétique); apokope (bortskæring af final orddel, eks: microordinateur -> micro - meget anvendt, især i fagjargon).

Til den anden gruppe, dén bestående af flere graford, er der først de leksikalske ellipser, eks: un (moteur à) quatre temps, også mest brugt i uformelle sammenhænge.

Dernæst et nu om dage kært barn, le mot-valise, mot-portemanteau, mot-centaure, mot-gigogne, mot-tiroir, mot contaminé, etc., der er en sammensmeltning på signifiant- og signifiéplan af to (evt. flere) selvstændige ord, en afkortelsesproces, der også går under navne som acronymie, haplologie, croisement, télescopage, amalgame, m.fl. En kilde (Clas 1987) opregner 6 forskellige undergrupper, hvori der alle indgår én el. flere af de tre ovennævnte afkortelsesprocesser. Flest eksempler er der af typen apokope + afærese: transpondeur <- transmetteur + répondeur, men dobbelt apokope er også almindelig: modem <- modulateur + démodulateur. Det samme gælder afærese af 1. ord: bureautique <- bureau + informatique. Bemærk hybriddannelsen: secam <- séquentiel à mémoire. Ord af typen télébenne: se 2.9.

Endelig initialordet, le sigle, som ligeledes traditionelt er af uvurdelig, praktisk betydning ikke mindst i specialicerede, ofte - men ikke altid jargonprægede sprogbrugssammenhænge. Det er en sammenkædning af et syntagmes initialbogstaver, en (som oftest) maksimal apokope. Eks- 
empler på forskellige typer: det lydligt integrerede $C A O$ (Conception Assistée par Ordinateur); det bogstaverede DCB (Décimal Codé Binaire). Eksempel med punkteringstegn L.M. (Langage Machine); med minuskler rpi (rangées par inch); med versaler og minuskler B.d.T. (Base de Temps); med græske eller alfanumeriske symboler $m \mu P$ (multimicroprocesseur); I ${ }^{2}$ L (Logique à Injection Intégrée; ses også som I $2 \mathrm{~L}$ og $I_{2} L$ ), og næsten alle tænkelige kombinationer og hybridgrupper af orddannelseskategorier... (se eksempel i 2.9 in fine).

\subsection{Lån}

Lån fra andre sprog (xenismer) er en kategori lidt til en side i denne sammenhæng. (Med "lån" menes i øvrigt normalt kun lån fra levende sprog, og i praksis har kun engelsk betydning i vor tid). Dens konstituenter omfatter i snæver orddannelsesmæssig forstand udelukkende ord overtaget fra et fremmed sprog uden ændring i den udenlandske grafi, og som derfor ikke er dannet i det franske orddannelsessystem, eks: benchmark (N, m(?)). Set ud fra en kontrastiv orddannelsessynsvinkel er alt, hvad der hedder lånte elementer imidlertid kriteriet for den videre klassifikation (jf. præsentationen af informatikterminologien, afsnit 4).

\subsection{Grammatiske og semantiske neologismer}

Fælles for de hidtil nævnte måder at danne nye ord på er for det første, at de ikke kan siges at finde typisk anvendelse kun i teknisk (eller kun i almindeligt) sprog, for det andet, at de for alles vedkommende - som det også er tilfældet for 2.8 og 2.9 - anvendes til at danne grafiske neologismer, også kaldet leksikalske eller formelle neologismer. Nye leksikalske enheder skal ikke kun søges på signifiant-siden. Til de grammatiske neologismer hører kategorien "ordklasseskift" (konversion), hvor f.eks. et adjektiv transformeres til et substantiv - eller omvendt - uden at grafien ændres, eks: silencieux (A) -> le silencieux (N), og kategorien semantiske neologismer, hvor allerede eksisterende grafier (ord) tillægges en ny betydning, eks: souris (N). Til denne kategori hører metaforer og metonymer (pars pro toto), eks: hv. mémoire og transistor.

\subsection{Leksikalske syntagmer}

Som nævnt under sammensætning, henregner mange dannelsen af leksikalske syntagmer til denne kategori. Uden at tillægge det grafiske aspekt overdreven betydning i en taksonomi er det hensigtsmæssigt i teknisk sprog at foretage en basal sondring mellem komposita og syntagmer. Leksikalisering af syntagmer forekommer også i ikke-tekniske registre, 
men blandt tekniske neologismer er leksikaliseringen af syntagmer sandsynligvis - og det bekræftes af egne undersøgelser - den hyppigst forekommende kategori af alle. Leksikalske syntagmer kan som ordklassesekvens optræde i mange skikkelser, men i praksis finder vi typisk: for 2grafords vedk.: $\mathrm{N}+\mathrm{A}$ (eks: mémoire externe) og $\mathrm{N}+\mathrm{N}$ (eks: mémoire tampon); for 3-grafords vedk.: $\mathrm{N}+\mathrm{P}+\mathrm{N}$ (eks: mémoire de travail) og $\mathrm{N}+\mathrm{A}+\mathrm{A}$ (eks: mémoire morte programmable) og for $4 \mathrm{ff}$-grafords vedk.: kombinationer af N, A, P, m.fl. (jeg har registreret både 10- og 11-grafords franske informatiklemmata), eks: enregistrement non polarisé avec retour à zéro; à quatre adresses d'opérande et une adresse de commande.

\section{9 "La formation savante" (konfiksation)}

Den traditionelt mest teknisk-specifikke orddannelseskategori er: "la formation savante" el. "la confixation", der danner ord ved hjælp af græsk-latinske elementer (traditionelt 2) og ordføjningsregler: les mots savants. Set i et diakront lys har fransk lånt fra disse såkaldte - men ikke helt - døde sprog i flere omgange, først selvfølgelig fra vulgærlatin. Fra skriftlige latinske kilder blev der op til det 16 . årh. lånt en lang række latinske og græske teoretiske fagord bl.a. inden for naturvidenskaberne, men konstruktionen af disse ord fandt ikke sted inden for rammerne af det franske sprog, da de jo eksisterede i forvejen. Men i det 16.-18. årh., hvor videnskaberne for alvor udviklede sig, krævede de mange nye begreber og materielle frembringelser udarbejdelsen af systematiserede terminologier, og videnskabsmænd og teknikere tyede til eksisterende græske og/eller latinske orddele, der blev sat sammen indbyrdes til nye ord, som i micro/scope. (For videnskabsgrene med svært iagttagbart eller kompliceret genstandsfelt som kemien konstruerede man et arbitrært, systematiserende suffikssystem; f.eks. indikerer -ite og -ate en kemisk distinktion i sulfite $(\mathrm{N})$ og sulfate $(\mathrm{N})$ med sulfureux $(\mathrm{A})$ og sulfurique (A) som de tilsvarende adjektiver). Da de fremmede orddele (oprindeligt) hverken optræder frit eller lægger sig til frie morfemer, har vi i princippet hverken at gøre med komposita eller affikser - man taler om konfikser (Martinet, Kocourek), eller blot "pseudo-suffikser/-affikser" eller "suffiksoider/præfiksoider" (f.eks. Haensch \& Lallemand- Rietkötter), eller slet og ret om "éléments savants (grecs/latins)" (f.eks. Grevisse; Goosse). Mange kan i øvrigt optræde i både post- og præposition i forskellige realisationer (eks: phono /gramme, grammo /phone).

Senere blev det ikke ualmindeligt at kombinere græsk/latinske elementer med franske, eks: télélcommunication; ordino/o/gramme. (I over- 
ensstemmelse med græsk orddannelse anvendes normalt bindevokal -ohvis første ord(del) ikke ender på vokal). Nogle produktive græsk/latinske bestanddele er ikke egentlige morfemer, men afkortede grafier, fraktomorfemer (Jean Tournier cit. i Rey-Debove 1986). I (1) télégraphe, (2) télécommunication, (3) téléspectateur og (4) télébenne, er det kun i (1) og (evt.) (2) at télé- er et konfiks ("fjern"), mens det i (3) og (4) er apokoperede versioner af hv. télévision og téléphérique.

Alle disse og i øvrigt også kombinationen latinsk+græsk i samme ord (eks: oscill /o /gramme), er traditionelt meget produktive, førstnævnte i flere af sprogets registre.

At mange leksikalske enheder er hybriddannelser (resultatet af en kombination af diverse orddannelsesprocesser) fremgår af flg. analyseforslag af en håndfuld informatiksubstantiver - i lighed, i øvrigt, med flere af de hidtil nævnte eksempler:

1) re/cycllage

parasyntetisk afledning med latinsk præfiks, græsk rod, fransk suffiks;

2) mini /tel /l /iste

suffiksering af præfikseret afærese/synkope $($ tel <- téléphone + terminal $; / l /=$ konsonantfordobling);

3) multiplex/age par répartition en fréquence

leksikalsk syntagme $(\mathrm{N}+\mathrm{P}+\mathrm{N}+\mathrm{P}+\mathrm{N})$, hvor $\mathrm{N}_{1}=$ suffiksering af lånt ("ex-nihilosuffikseret") adjektiv (multiple /x/age <- multiple (eng. A));

4) non-EAO/iste

konfiksering af suffikseret initialord;

5) bit drapeau sammensætning af (apokoperet+afæreseret) låneord (bit <- $\underline{\text { binary digit }) \text { og }}$ semantisk neologisme.

\section{Om informatique}

Når jeg har valgt netop informatikområdet som genstandsfelt for undersøgelser af orddannelsen i teknisk fransk - jeg forenkler her ved at forudsætte informatikterminologien som tilhørende ét fagsprog - skyldes det ikke mindst den kendsgerning, at kommunikations- og informationsbehandlingsteknologierne ubestridt er de seneste årtiers mest vidtfavnende, mest transformerende, mest vulgariserede teknologier, som på én gang er tilstrækkeligt etablerede til at have fået deres egen, alment accepterede og attesterede terminolgi, på én gang stadig er i så stærk udvikling, at de bærer et frugtbart terminologisk vækstpotentiale i svøb.

Termen informatique er i modsætning til næsten alle andre ord inden for informatikken af fransk oprindelse, konstrueret i 1962 af en elektro- 
nikingeniør, der savnede et ord for det, han arbejdede med, nemlig elektroniske regnemaskiner, som datamaten el. computeren hed dengang. Da arbejdets formål var automatisk informationsbehandling, og han indså det praktiske $\mathrm{i}$ at lave et ord, der associerede i retning af elektronik og matematik, satte han første halvdel af information og anden af automatique sammen til informatique, altså et mot-valise.

informatique anvendes på fransk i en snæver og i en bred betydning, hvor den snævre dækker den officielle definition, som refererer til det tekniske aspekt, databehandlingen i datamaskiner, evt. også datatransmissionen (svarer på dansk og engelsk traditionelt til "edb" og "data processing"), mens den bredere betydning henviser til den videnskabelige, matematikbaserede disciplin informationsvidenskab (= les sciences de l'information; på engelsk evt. informatics). Der synes at være en klar tendens til i disse år at anvende den suggestive benævnelse informatik i en stadig bredere betydning - ikke mindst på dansk; ud over om det snævert tekniske og det bredere teoretiske desuden om alt, der vedrører anvendte aspekter. Den mere og mere omfattende indholdsside af informatique skyldes udover det faktum, at vi har at gøre med et teknisk-videnskabeligt område i eksplosiv udvikling også, at der er grundlæggende divergerende holdninger til, hvad benævnelsen bør dække: nogle trækker i den teknisk-anvendelsesmæssige, andre i den videnskabelig-teoretiske retning, og informatique - i modsætning til en længere række foreslåede og/eller udkonkurrerede alternativer som ordinatique, intellectronique, programmatique,... - er den mindste fællesnævner, kompromis'et.

\section{Informatikterminologiske karakteristika}

Hvad ved vi om orddannelsen indenfor informationsteknologien?

Informatikterminologien i bred forstand har været og er $\emptyset$ jensynligt genstand for ret få forskningsprojekter. Jeg er ikke stødt på én eneste artikel om emnet på engelsk, selvom næsten alle ord præges på dette sprog. I de fransktalende lande har den været genstand for undersøgelser af en håndfuld sprogfolk. Da denne første generations frankofone litteratur om de franske ækvivalenter til de engelske neologismer overvejende naturligt nok er af typen kontrastiv behandling, hvis taksonomi bygger på oversættelses- mere end de hidtil præsenterede orddannelseskriterier, vil min (forsøgt tilpassede) fremstilling til en vis grad bære præg heraf, men med som følge en række kontekstiagttagelser, der vil kunne bidrage til at stille orddannelsen i relief og få aktuelle tendenser til at fremstå i et forklarende lys. 


\subsection{Ifl C Marcellesi}

I 1970'erne undersøgte Christiane Marcellesi, Nanterre, som sandsynligvis den første, sprogbrugen, skriftlig som mundtlig, blandt franske edb-beskæftigede på forskellige niveauer. Hun konstaterede, at informatikterminologien er et meget omfattende leksikalsk felt opbygget næsten synkront på mindre end et årti og mente at kunne fastslå, at de officielle og ikke-officielle normaliserings- og standardiseringsmyndigheder (herunder IBM-France) allerede på det tidspunkt havde gjort en meget stor indsats for at reducere antallet af direkte lån fra engelsk til fordel for franske oversættelseslån (calques) og i enkelte tilfælde "neologismer afledt af ædle rødder", dvs. afledninger med græsk/latinsk basis. Ifl. Marcellesi er forskellen i mundtlig og skriftlig sprogbrug udtalt: betydelig større brug i den mundtlige kommunikation af engelske ord, af brachygrafiske former (især apokoperede som macro, perfo...) og af komplekse termer sammensat uden præpositioner efter engelsk mønster (analysebande; erreur-programme). Lighederne mellem mundtlig og skriftlig sprogbrug er en høj frekvens af forkortelser og telegramstil samt en vis forekomst af verber afledt af engelsk (bufforiser, canceler, lister...).

\subsection{Ifl G Lurquin}

I begyndelsen af 80'erne interesserede Georges Lurquin, Bruxelles, sig for informatiksproget, især hvad angår syntaktiske og morfologiske karakteristika. Han inddeler selv de leksikalske enheder i 5 hovedgrupper (Lurquin 1982a):

1) Semantiske neologismer, der er overtaget fra almensproget

De omfatter, med stor associativ effekt, dagligdags benævnelser fra menneske- og dyreverdenen, valgt bl.a. for at afmystificere en teknologi, hvis kapacitet og effektivitet overstiger manges fatteevne. Engelske eksempler: bug, hopper, garbage,... Rigtig mange enheder er antropomorfe metaforer: der er talrige referencer til legemsdele (bras de lecture, tête d'écriture, cou de code) og datamaskinens handlinger og egenskaber er gjort menneskelige: l'ordinateur analyse, saisit, traite, interroge, répond, enseigne.... man taler om intelligence, cerveau, mémoire, avortement.

2) Semantiske neologismer, der er overtaget fra andre fagsprog Her nævner Lurquin kun logik, matematik - og teologi. Det sidste er 
et kuriosum og drejer sig om det franske ord for datamaskine, ordinateur. Hvad angår matematikken, gælder det ord som algorithme, interpolation, matrice..., som delvis bevarer deres oprindelige betydning, alt imens de anvendt $\mathrm{i}$ informatikken får tilført noget specifikt nyt. En række ord er genbrug på en anden led: (E) control unit, card puncher, input-output, m.fl. blev også brugt om datamaskinens tidligste forgængere, 1700- og 1800-tallets aritmetiske regnemaskiner.

3) Grammatiske neologismer - ordklasseskift

Informatikkens engelske terminologi er kendetegnet ved sin multiordklassetilknytning; således transformeres ubesværet en lang række ordklasser og orddannelseskategorier til verber, eks: transformation af N:to queue; af Konj: to and; af A: to slow; af reduktion: to dupe (duplicate); af produktnavn: to teletype; af kompositum: to pingpong; af initialord: to ellesify ( $L S I)$.

4) Lån

Lurquin påviser, at flere af de engelske lån i virkeligheden er af fransk oprindelse, eks: maintenance; label.

5) Grafiske neologismer

Taget under ét dannes der færre grafiske end semantiske neologismer, hævder Lurquin. Han giver en række eksempler på den karakteristiske brug af diminutivpræfikserne mini-, og især micro-, i mindre grad nano- og pico-, som i mini-ordinateur; micro-processeur; nano-électronique; pico-seconde, alle præfikser, der afspejler den tiltagende "miniaturisering" på informatikområdet.

Lurquin beskæftiger sig derudover indgående med, hvad man kunne kalde de "nye" suffikser, der indgår i en længere serie beslægtede ord, der refererer til de nye teknologier. Det drejer sig først og fremmest om -matique, i forkortede (senere) varianter -atique el. -tique som i téléinformatique -> télématique -> télétique [eksemplet, der også er gengivet $\mathrm{i}$ Lurquin 1982b, synes ikke at have gyldighed (i dag): ifl. Dictionnaire des néologismes officiels (1988), der ikke angiver télétique, har de to første termer afvigende betydninger]. Eksempler modelleret efter informatique: robotique, productique, bureautique, documentique,...[man kunne tilføje privatique, domotique, monétique, connectique, médiatique, vidéotique, bancatique, etc.] med betydningen område, metode el. proces baseret på informationsteknologi. Der er her tale om en gammel kending: orddannelse ved analogi. I naturvidenskaberne er der tradition for, at man tager 
en ordendelse, som ikke eksisterer i sproget som suffiks (morfem). Et klassisk eksempel fra fysikken er endelsen -(tr)on [, der fra électron (opr. électro- + (io)n) dannede suffiks i andre partikelbenævnelser som neutr/on for senere også at indgå først i cyclo/tron (= partikelaccelerator), senere f.eks. i magnéltron og synchro/tron, hvor -tron i begge tilfælde nu er en afæreseret form af cyclotron og ikke électron [min uddybning]]. Fremkomsten af de moderne teknikker har mangedoblet denne analoge suffiksering. Det samme gælder det andet nye, lige så uklart afgrænsede suffiks, -giciel, -iciel, -ciel, evt. -iel eller -el som i basisinformatiktermerne matériel og logiciel (= hardware/materiel, hv. software/programmel), et suffiks, der bl.a. er inspireret af det kategoriserende adjektivsuffiks -el, især i dets anvendelse i matematiske discipliner: différentiel, séquenciel, matriciel, hvorfra det overføres og senere evt. transformeres til et substantiv. Eks. kopieret efter logiciel: progiciel, didacticiel, séquenciel, ludiciel,... i betydningen data-programmel af typen $\mathrm{X}$.

M.h.t. syntagmatisk brachygrafi, er der i engelsk en tiltagende tendens til eksempler på sammentrækninger af både ord og syntagmer, en sammentrækning, der synes at ske mere efter tilfældige end morfematiske kriterier: (E) info <- information; perfs <- perforations; nand <- not and; pel <- picture element. Med størst frekvens forekommer dog initialordene, der indgår som en fonetisk sekvens i talesproget på lige fod med andre orddannelsesformer og derfor kan danne basis for suffiksation som $\mathrm{i}$ (E) ROMable, Dper (= data processing man).

Endelig omtales en måske kommende måde at sætte ord sammen på, hvor det finale element kobles direkte på det første uden blanktegn eller bindestreg, men med stort begyndelsesbogstav, som det ses i proprier i reklamesproget: TermNet.

[Til nogle af Lurquins og i øvrigt også andres eksempler vil jeg i parentes anføre, at den teknologi, de refererer til, i dag er forældet, f.eks. alt, der refererer til hulkort, men nye metaforer kommer stadig til, eks: souris, pirate, bus,... ].

\subsection{Ifl V Prince}

To franske forskere, Violaine Prince og John Humbley, har hver for sig foretaget sammenligninger af engelsk og fransk informatikterminologi med bl.a. disse kontrastive iagttagelser til følge:

Violaine Prince har undersøgt en række forskellige teksttyper og præsenterer først en række karakteristiske engelske informatikord: "joker- 
ordene", dvs. højfrekvente substantiver som system, support, process, hvis reference oftest kun kan afgøres af den fraseologiske kontekst; eufoniske (dvs. velklingende) ord, som enstavelsesordene patch, slash, stack, $\log$ og endelig de "overdrevent" mange initialord. Dernæst opregner hun nogle kvaliteter ved engelske enheder, der fremmer sandsynligheden for en direkte overtagelse $\mathrm{i}$ fransk frem for alternativet en låneoversættelse, nemlig god overensstemmelse mellem indholds- og udtryksside, korthed, mnemoteknisk karakter og let udtale/eufoni.

Prince's hovedsynspunkt er, at der via den engelske informatikterminologi sker en markant leksikalsk forarmelse af det franske sprog, først og fremmest fordi den sproglige kontakt giver sig udslag i en semantisk (og/eller grafisk) transformation af morfemer i franske leksikalske enheder, inklusive og især i dem, der er fælles for engelsk og fransk og/eller oprindeligt er franske, herunder en tendens til brug af leksikalske enheder, "qui ressemblerait à une mauvaise traduction d'un américain déjà approximatif" (Prince 1986, 34). Eksempler er joker-verber som nécessiter, traiter, accéder. En anden gruppe er ord, der foretrækkes "på grund" og ikke på trods af deres længde, eks: expliciter i betydningen expliquer; sélectionner i bet. choisir; optionner i bet. opter. Endelig den mest betydningsfulde gruppe, der inkluderer "les faux amis", hvor betydningen er direkte vildledende eller uheldig på anden vis. Eks: inconsistant for incohérent; compactifier for comprimer; significative for sémantique; collecter for recueillir.

\subsection{Ifl J Humbley}

John Humbley forsker i disse år i fransk og tysk informatikterminologi fra tekstkorpora og ordbogslemmata og kontrasterer med tilsvarende engelske enheder. På basis heraf kan han for det første informere os om, at anglificeringen af tysk er langt mere markant på alle måder, og at de franske informatikterminologikommissioners termlister stort set har været en succes. Han påpeger, at oversættelse af den engelske term typisk sker indenfor de abstrakte områder af informatiken, mens konkrete benævnelser oftest bliver overtaget uændret, men grænsen mellem konkret og abstrakt er meget svær at trække i informatik, hvor substantiverne ofte er polyvalente.

Der findes øjensynligt yderst få kvantitative oplysninger vedrørende fransk informatikterminologis morfologi. Humbley har dog (i Humbley 1987b) undersøgt 1981-udgaven af en kendt fransk informatikordbog (P. Morvan: Dictionnaire de l'informatique, Larousse) og fundet, at af de to- 
talt ca. 1530 lemmata er $36 \%$ af klar græsk-latinsk etymologi (som: logimètre) mod kun $7 \%$ af germansk eller angel-saxisk oprindelse (som: smalltalk), $5 \%$ blandet (som: call confirmation) og $52 \%$ af ikke umiddelbart identificerbar herkomst. På denne baggrund mener han, at fransk er i en favorabel situation, idet mere end hvert tredje informatikord glider ind i den franske terminologi takket være den fælles græsk-latinske sproglige arv, oftest uden anden tilpasning end en ombytning af ordføjningsrækkefølgen i de komplekse enheder fra regressiv til progressiv som i eks: (E) expert system -> (F) système expert.

Humbley har endvidere foretaget en række detaljerede, kontrastive undersøgelser med basis dels i ordbogsmateriale, dels i de officielt påbudte termer, og dels i tidsskriftartikler for så bredt og pålideligt som muligt at få indsigt i transformationssprocessen $\mathrm{E}->\mathrm{F}$, hvor hans udgangspunkt er antagelsen om, at de franske informatikord kan siges at være en slags afledte størrelser af en engelsk model, som han vil identificere (Humbley 1988). Det vil dog føre for vidt at her præsentere hans omfattende analyser og interessante ækvivalensskemaer.

Humbley har også analyseret de franske informatikord m.h.t. deres komponent af semantisk lån, som også han siger er selve basis for terminologien, da den forekommer i langt højere grad end ekstremerne direkte lån på den ene side og den helt ny form på den anden (Humbley 1987a). Den typiske franske leksikalske enhed har nemlig et mere eller mindre og især mindre - transparent præg af kopiering af den engelske ækvivalent - på indholds- og/eller udtrykssiden - uden dog at være en grafisk afstøbning.

Han bemærker i øvrigt, at affiksering i fransk er en hyppigere måde at danne ord på end i engelsk, og at kun ca. $10 \%$ af de franske informatikord er direkte lån.

\subsection{Ifl D Nakos}

Dorothy Nakos, Québec, er sidste levende billede. Også hun arbejder kontrastivt, på basis af officielle canadiske og franske termer, m.h.p. at få viden om substantivsyntagmernes karakteristika.

Nakos mener, at de nye teknologiers terminologier er karakteristiske bl.a. ved forholdsvis mange syntagmer, men at fransk har sværere end engelsk ved at kæde morfemer og graford sammen til komplekse enheder, i hvert fald udviser fransk større heterogenitet her end engelsk.

Traditionelt benytter F sig af præpositioner til at sammenkæde de frie morfemer i syntagmerne, hvilket har den fordel, at relationerne mellem 
morfemerne præciseres. I den forbindelse nævner Nakos, at den i teknisk sprog ellers så almindelige $\mathrm{N}+\mathrm{a}+\mathrm{Inf}$ (machine à écrire) næsten er uopdrivelig; der foretrækkes $\mathrm{N}+\mathrm{de}+\mathrm{N}$ som programme de dépistage frem for * programme à dépister.

En hel del iagttagelser peger i retning af høj frekvens af diverse former for brachygrafi i de leksikalske elementer:

Først og fremmest "det meget store antal" N+N-konstruktioner, der efter engelsk model er resultatet af sammenkoblinger af substantiv-graford til syntagmer uden præpositioner. Denne orddannelsesform har den ulempe, at relationen mellem syntagmets bestanddele kan være tve- eller mangetydig, men det er vigtigt at bemærke sig, at det er karakteristisk for informatikken, at et syntagmes elementer tit er sideordnede, et udtryk for forløbet mellem to operationer af lige stor betydning. Eksempler: retraitrappel; récepteur-perforateur non imprimeur. Syntagmer uden præposition(er) giver i $\emptyset$ vrigt ofte indtryk af et hele bestående af diverse elementer og ikke, som (franske) præpositionssyntagmer, af flere komponenter sat sammen til et hele.

Et par andre eksempler på preferencen for korte leksikalske enheder er initialordene og diverse sammentrækninger, som begge skulle være "très important" i fagsprog "notamment en informatique".

Inden for kategorien syntagmer nævner hun også den klassiske N+Aform, hvor der er fuld morfologisk overensstemmelse mellem $\mathrm{E}$ og $\mathrm{F}$.

Andre iagttagelser er en stor procentdel eponymer, dvs. ord med personreference (code Gray) og endnu et træk kopieret fra engelsk, brug af småord - sat i relief af majuskler - der indgår i syntagmer, som ET câblé; $O U$ exclusif.

Nakos er sikker på, at de lange syntagmer en dag vil være glemt, erstattet af brachygrafiske ækvivalenter.

\subsection{Opsamling og udledning}

Lad mig på basis af forskningen i fransk informatikterminologi lave en opsamling vedrørende dens fordeling på orddannelseskategorierne.

For det første er der ret bred enighed om, at myten om informationsteknologiernes høje indhold af engelske ord i fransk ikke har meget på sig, i hvert fald ikke hvad angår direkte lån, mens paralleller på signifiant-plan til engelske morfemer, herunder affikser, derimod er yderst talrige.

For det andet viser det sig, at den engelske basis for informatikterminologien i vid udstrækning er genbrug af eksisterende engelske signifi- 
ants, der får en supplerende signifié; disse semantiske neologismer oversættes til fransk ofte ved en parallel metafor, der typisk er et simpelt ord.

I et flertal af tilfælde sker der (også) en grafisk transformation af en eller anden slags. Det franske sprog har en mængde forskelligartede midler til rådighed, når det gælder om at transformere, evt. helt omstøbe de engelske ord, midler hvis succes skulle afspejles i den faktiske sprogbrug, i hvert fald den delvis normaliserede skriftlige.

Der er efter al sandsynlighed tale om en markant tendens i retning af stor eller stigende forekomst af leksikalsk brachygrafi, især initialord af alle tænkelige typer, men også mot-valises, der øjensynligt ikke sjældent konstrueres meget tilfældigt.

Vedr. de talrige syntagmer er at bemærke den store mangfoldighed i typer og de måske relativt mange $\mathrm{N}+\mathrm{N}$-konstruktioner og nye konstruktioner som f.eks. Konj.+A.

Om traditionel afledning og sammensætning har vi ikke meget information; vi ved dog, at der generelt er mange komplekse enheder, og at fransk kan danne afledninger på basis af engelske enheder og f.eks. af komposita og initialord, og at en række evt. mere eller mindre specifikke affikser, konfikser og fraktomorfemer m.m. er hyppigt brugt. I den forbindelse er det bemærkelsesværdigt, at ingen kilder betoner "la formation savante" som værende væsentlig i informatikterminologien - og ej heller det modsatte. Det samme gælder (stort set) kategorierne "ex nihilo", "reduplikation" og "onomatopoietikon".

Et sammenfattende, kondenseret udtryk for orddannelseskarakteristika i fransk informatikterminologi kan være følgende:

Fransk informatikterminologi er karakteriseret ved på den ene side simple, semantiske neologismer, på den anden side ved mangeartede, analytiske syntagmer og brachygrafisk prægede syntetiske konglomerater af (systematiseret) komposition, derivation og konfiksation.

Ret meget nærmere kan vi næppe komme, vores kilders fătallighed og for nogles vedkommende begrænsede brugbarhed taget $\mathrm{i}$ betragtning.

På baggrund af ovenstående karakteristika ved orddannelsen inden for informatikken vil det være meget fristende at ekstrapolere til udviklingstendenserne for teknisk fransk som sådan. Hvis vi kan acceptere realiteten af den traditionelle benævnelse "teknisk sprog" som én relativt homogen fagsprogsgruppe og godtager, at informatikområdet om noget områ- 
de er eksponenten for den teknologiske udvikling i disse årtier (la biotique venter i kulissen !), er der kun en hårsbredde til udledningen: "orddannelsen i informatikterminologien er det bedste enkeltbud vi har på udviklingstendenserne i orddannelsen i teknisk sprog". Kan vi samtidig få bekræftet vores orddannelsesudsagn fra andre relevante lingvistiske kilder end dem, der fokuserer på netop informationsteknologi, øges sandsynligheden væsentligt. - Og det kan vi øjensynligt.

Et blik på en række nyere, fagsprogsorienterede kilder (Ibrahim 1986a, 1986b; Kocourek 1982; Lurquin 1982b; Otman 1986; Rey-Debove 1986; Robinson 1983) leder os nemlig til to generelle udsagn vedrørende udviklingen i orddannelsen, udsagn som harmonerer med vores sammenfattende udtryk for orddannelseskarakteristika i fransk informatikterminologi:

\section{1) stigende tendens til nydannelser præget af på én gang arbitrær mangfoldighed og systematiseret analogi, jf:}

"... cette liberté totale, que j'appelle morphologie sauvage, commence à servir de modèle pour la néologie française" (Rey-Debove 1986, 51);

"... on suffixe, préfixe, verbalise, nominalise et télescope en faisant comme si tous les mots étaient permis et compris dès lors que le sens et le but du mécanisme qui leurs a formés ont été perçus" (Ibrahim 1986a, 83);

"L'un des aspects remarquables de cette production de mots nouveaux est, dans sa phase la plus récente, son caractère systématique" (Lurquin 1982b, 300);

2) stigende tendens til på én gang morfologiske og syntaktiske nydannelser i form af hv. kombinationer af afledning, sammensætning, konfiksation og brachygrafi, hv. syntagmer, jf:

"... on suffixe, préfixe, verbalise, nominalise et télescope... " (se op cit.);

"La préfixation [au moyen d'éléments savants du type télé-, audio-, [min tilføjelse]] est un mode de création de néologismes très vivant et productif en français dans le domaine des technologies nouvelles" (Otman 1986, 41);

"La tendance actuelle est de modifier les emprunts et en particulier les syllabes terminales" (Ibid., 39);

"La confixation est toujours un schéma très puissant et productif de la formation terminologique...(or) la tendance hellénisante et latinisante était plus forte il y a cent ans" (Kocourek 1982, 109);

"... the greater currency of substantive + de + substantive-compounds" (Robinson 1983, 31);

"La forme de composition anglo-américaine, par juxtaposition directe des composants avec ellipse de la préposition pénètre de plus en plus en français..." (Lurquin 
1982b, 291).

Blot savner vi støtte for vigtigheden af de semantiske neologismer, hvilket næppe er en tilfældighed. Orddannelseslitteraturen er traditionelt mere morfologisk end semantisk orienteret, og jeg forestiller mig samtidig, at netop den semantiske genbrug af ord fra almene registre er særlig karakteristisk for de nye teknologier.

Hvis vi ser bort fra dette punkt, vil vi, parallelt med udtrykket for informatikterminologien (og alt andet lige), kunne opstille følgende tilnærmede udtryk for den sandsynlige udvikling i orddannelsen i teknisk fransk:

Fransk teknisk terminologi vil fremover i stigende grad være præget af på den ene side mangeartede, analytiske syntagmer, på den anden side af brachygrafisk prægede, syntetiske konglomerater af (systematiseret) komposition, derivation og konfiksation.

\section{Udblik}

Et så relativt bredt udtryk for den sandsynlige udvikling i orddannelsen i teknisk fransk som det ovenstående afføder naturligvis en række ubesvarede spørgsmål. Der er stadig mange for teknisk terminologi væsentlige orddannelsesmæssige forhold, vi ved for lidt om eller som burde tages op til empirisk efterprøvning på grundlag af de nye teknologiers terminologi, al den stund udviklingen går så stærkt og får stadig større konsekvenser for stadig bredere brugergrupper. Perspektiver anes og spørgsmålene trænger sig på. Bl.a. finder jeg følgende essentielle:

- er de traditionelle orddannelseskategorier, der bygger på en almensproglig klassifikation, ikke så stive og snævre, at der kunne være fare for, at de mere virker som en hæmsko end som det smidige klassifikationsværktøj, de burde være ? (jf. Boissy 1988, 77: "Bon nombre de formations lexicales en langue de spécialité échappent aux taxinomies classiquement proposées qui montrent par des systèmes clos les procédés de création de la langue générale. Or, le réel transgresse ces taxinomies car ces découpages ne sont jamais que des visions particulières");

- kan det underbygges, at neologismerne i de nye teknologier har tendens til at være præget over forskellige læste alt efter en række ekstralingvistiske forhold, således at der er stфrre sandsynlighed for, at en neologisme er et analytisk (definitions)syntagme end en syntetiskmorfologisk enhed, hvis: 
1) den er undfanget på et fremmed sprog (en betegnelse for et nyt, udenlandsk fænomen),

2) den er kreeret i et teoretisk-videnskabeligt miljø,

3) den har en relativt specialiseret betydning,

4) den er førstegangs-benævnelse for fænomenet;

\section{og omvendt, hvis:}

1) den er formet første gang på fransk (en fransk opfindelse el.lign.), eller er resultatet af en officiel normering,

2) dens udformning er blevet til i et praktisk-teknisk miljø,

3) den har relativt lav specialiseringsgrad,

4) den ikke er førstegangs-benævnelse;

- vil man kunne opstille strukturelle regler for nye morfematiske realisationer, herunder gennemskue den tilsyneladende arbitraritet i de brachygrafiske elementer?

- kan det godtgøres, at informatikkens nye teknologiindhold signifikant påvirker suffiksfrekvenserne i retning af vigende tendens for a) visse traditionelle højfrekvente substantivsuffikser af kategorierne nomina actionis, agentis og/eller instrumenti til fordel for andre, herunder "de nye informatiksuffikser" (en "ekstrapolation" af Dubois 1962) eller b) andre mindre produktive substantivsuffikser ?

- er der belæg for en tendens til bortfald af præposition mellem substantiver i syntagmer, så man må forvente forholdsvis flere neologismer af typen $\mathrm{N}+\mathrm{N}$ på bekostning af typen $\mathrm{N}+\mathrm{P}+\mathrm{N}-\mathrm{og}$ i givet fald $\mathrm{i}$ hvilke semantiske og syntaktiske kontekster?

- kan det afvises, at den traditionelt franske progressive ordfølge undermineres af den bl.a. engelske regressive (f.eks. $\mathrm{A}+\mathrm{N}$ i stedet for den progressive $\mathrm{N}+\mathrm{A})$ ?

- vil empiriske undersøgelser bekræfte formodningen om et med informatikterminologien voksende behov for inddragelse af på den ene side tekstuelle, på den anden side sociolingvistiske parametre til afgørelse af en vilkårlig fagterms semantiske reference?

- vil det ikke med informatikkens fremmarch være nødvendigt på en række punkter at nuancere, måske revidere udbredte forestillinger om "tekniske ords" karakteristika?

- bør man ikke stille spørgsmålstegn ved det hensigtsmæssige i opretholdelsen af traditionen for opdeling af fagsprogene efter genstands- 
felt, herunder en tendens til blokopfattelse af de tekniske discipliner og registre, i stedet overveje en opdeling efter måske mere frugtbare kommunikationskriterier?

Og endelig:

- må man ikke formode, at en (om muligt) diakron analyse af orddannelsen i en fagterminologi i vækst vil give meget større indsigt i den dynamik, der i sidste ende også spiller en rolle for almensprogets leksikalsk-strukturelle udvikling?

\section{Litteratur}

Bares, Karel (1974): Unconventional Word-Forming Patterns in Present-Day English, i: Philologica Pragensia 17, 1974, 173-186.

Boissy, J. (1988): Tendences linguistiques de la néologie en terminologie, i: La banque des mots (numéro spécial) 1988, 77-83.

Breton, Philippe (1985): Quelques précisions sur l'origine et l'histoire de trois termes en rapport avec une identité disciplinaire: INFORMATIQUE - ORDINATEUR - INFORMATION, i: Le langage et l'homme 20, 1985, 3-11.

Camille, Claude/ Dehaine, Michel (1970): Dictionnaire de l'informatique - Dictionary of data processing. Vol. II: Français-Anglais, French-English. London: Harrap 1970.

Camille, Claude/ Dehaine, Michel (1985): Harrap's informatique dictionnaire. AnglaisFrançais, Français-Anglais. London: Harrap 1985.

Clas, André (1987): Une matrice terminologique universelle: la brachygraphie gigogne, i: Meta 32, 1987, 347-357.

Dictionnaire des néologismes officiels. Commissariat général de la langue française. Paris: Journal Officiel de la République Française 1988.

Didi-Kidiri, M./ Joly, H./ Murcia, C. (1981): Guide de la néologie, Paris: CILF 1981.

Dubois, Jean (1962): Etude sur la dérivation suffixale en français moderne et contemporain. Paris: Librairie Larousse 1962.

Glouzman, I.S./ Borovikova, L.I. (1987): Dictionnaire français-russe de l'informatique. Moskva: Rousski Yazyk 1987.

Goosse, André (1975): La néologie française aujourd'hui. Paris: Conseil International de la Langue Française 1975.

Grevisse, Maurice (1988): Le bon usage - grammaire française. Ed. refondue par André Goosse. Paris: Duculot 1988.

Guilbert, Louis (1971): De la formation des unités lexicales, i: Introduction au Grand Larousse de la langue française, T. I, Paris: Larousse 1971, IX-LXXXI.

Haensch, Günther/ Lallemand-Rietkötter, Annette (1972): Wortbildungslehre des modernen Französisch. München: Max Hueber Verlag 1972.

Humbley, John (1987a): L'emprunt sémantique dans la terminologie de l'informatique, i: Meta 32, 1987, 321-325.

Humbley, John (1987b): La pénétration de l'anglais dans le français et l'allemand de l'informatique: étude contrastive, i: Contrastes 14-15, 1987, 263-277.

Humbley, John (1988): Comment le français et l'allemand aménagent la terminologie de l'informatique, i: La banque des mots (numéro spécial) 1988, 85- 148.

Ibrahim, Helmy (1986a): Confirmation de tendences, i: Le Français dans le Monde 201, 
1986, 83-85.

Ibrahim, Helmy (1986b): Les néologismes en -tique et en -ciel: radioscopie d'une réussite, i: Le Français dans le Monde 205, 1986, 75-78.

Kastovsky, Dieter (1977): Word-Formation, or: At the Crossroads of Morphology, Syntax, Semantics, and the Lexicon, i: Folia Linguistica 10, 1977, 1-33.

Kesselring, Wilhelm (1970): Grundlagen der französischen Sprachgeschichte. Band 1: Die französischen Sprache im 20. Jahrhundert. Tübingen: Tübinger Beiträge zur Linguistik 1970.

Kocourek, Rostislav (1982): La langue française de la technique et de la science. Wiesbaden: Brandstetter Verlag 1982.

Lurquin, Georges (1982a): La langue spéciale des informaticiens, i: Le langage et l'homme $17,1982,56-89$.

Lurquin, Georges (1982b): La néonymie scientifique et technique, i: Terminologies for the Eighties. Infoterm Series 7. Ed. by Internat. Information Centre for terminology. München: Saur 1982.

Lurquin, Georges (1986): La littérature périodique pour informaticiens et usagers de l'ordinateur, i: Le journal de réflexion sur l'informatique de l'Institut informatique des Facultés Notre-Dame de la Paix, Namur, 3, 1986, 25-28.

Marcellesi, Christiane (1973): Le langage des techniciens de l'informatique: quelques aspects de leur vocabulaire écrit et oral, i: Langue Française 17, 1973, 59-71.

Martinet, André (1979): Grammaire fonctionnelle du français. Didier: Paris 1979.

Messner, Dieter (1977): Einführung in die Geschichte des französischen Wortschatzes. Darmstadt: Wissenschaftliche Buchgesellschaft 1977.

Müller, Bodo (1985): Le français aujourd'hui. Paris: Klincksieck 1985.

Møller, Bernt (1987): Fransk sprogprotektionisme - en beretning om anglicismebrug, purisme og sproglovgivning i dagens Frankrig. Speciale, HНА 1987.

Nakos, Dorothy (1988): Les syntagmes terminologiques dans le domaine de l'informatique (étude comparée de l'anglais et du français). Upubl. ms. fra The 2nd Eindhoven Symposium on LSP, August 3-6, 1988.

Otman, Gabriel (1986): Technologies nouvelles cherchent néologismes, i: Le Français dans le Monde 202, 1986, 38-41.

Pavel, Sylvia (1988): Siglaison et créativité lexicale en intelligence artificielle, i: L'Actualité terminologique 21, 1988, 1-4.

Pierson, G. (1981): Informatique = data processing; informatics = sciences de l'information, i: La banque des mots 21, 1981, 19-43.

Prince, Violaine (1986): La pidginisation du français par le jargon américain de l'informatique, i: Actes du Deuxième Colloque du GEPE 23-24 mai 1986, Strasbourg. Ed. par C. Truchot et al. Strasbourg: Université des Sciences Humaines de Strasbourg 1986, 15-37.

Rey-Debove, Josette (1986): Incidences de l'anglais sur la morphologie française, i: Actes du Deuxième Colloque du GEPE 23-24 mai 1986, Strasbourg. Ed. par C. Truchot et al. Strasbourg: Université des Sciences Humaines de Strasbourg 1986, 45-53.

Robinson, A.H. (1983): Changing patterns of Word-Formation in French Technical Vocabulary, i: The Incorporated Linguist 22, 1983, 30-31. 